University of Nebraska - Lincoln

DigitalCommons@University of Nebraska - Lincoln

USDA National Wildlife Research Center - Staff Publications
U.S. Department of Agriculture: Animal and Plant Health Inspection Service

November 2004

\title{
Attractiveness of brown rice baits to non-target birds in harvested corn and soybean fields
}

George M. Linz

USDA/APHIS/WS National Wildlife Research Center, george_m_linz@yahoo.com

Gregory A. Knutsen

North Dakota State University, Fargo

H. Jeffrey Homan

US Department of Agriculture, Wildlife Services, National Wildlife Research Center

William J. Bleier

North Dakota State University, Fargo

Follow this and additional works at: https://digitalcommons.unl.edu/icwdm_usdanwrc

Part of the Environmental Sciences Commons

Linz, George M.; Knutsen, Gregory A.; Homan, H. Jeffrey ; and Bleier, William J., "Attractiveness of brown rice baits to non-target birds in harvested corn and soybean fields" (2004). USDA National Wildlife Research Center - Staff Publications. 357.

https://digitalcommons.unl.edu/icwdm_usdanwrc/357

This Article is brought to you for free and open access by the U.S. Department of Agriculture: Animal and Plant Health Inspection Service at DigitalCommons@University of Nebraska - Lincoln. It has been accepted for inclusion in USDA National Wildlife Research Center - Staff Publications by an authorized administrator of DigitalCommons@University of Nebraska - Lincoln. 


\title{
Attractiveness of brown rice baits to non-target birds in harvested corn and soybean fields
}

\author{
George M Linz, ${ }^{1 *}$ Gregory A Knutsen, ${ }^{2 \dagger} \mathrm{H}$ Jeffrey Homan ${ }^{1}$ and William J Bleier ${ }^{2}$ \\ 1 US Department of Agriculture, Wildlife Services, National Wildlife Research Center, Great Plains Field Station, 2110 Miriam Circle, \\ Bismarck, ND 58501, USA \\ ${ }^{2}$ Department of Biological Sciences, Stevens Hall, North Dakota State University, Fargo, ND 58105, USA
}

\begin{abstract}
Brown rice is used as a bait-carrier for the avicide DRC-1339 (3-chloro-4-methylaniline) when baiting blackbirds (Icteridae). In March and April 1996 and 1997, we assessed non-target granivorous bird use of rice-baited plots placed in harvested corn and soybean fields in eastern South Dakota for 168 observation hours. In both years combined, we identified 10 and 14 granivorous species in corn and soybean fields, respectively. In $1996(X=0.2, \mathrm{SE}=0.04)$ and $1997(X=1.2, \mathrm{SE}=0.38)$, total numbers of granivores $\min ^{-1}$ were similar between crops $(P \geq 0.322)$. In 1996 , bird numbers were higher $(P=0.069)$ in rice-baited fields $(X=0.3, S E=0.07)$ than in unbaited reference fields $(X=0.1, S E=0.04)$. In 1997, bird numbers $(X=1.2, \mathrm{SE}=0.38)$ did not differ between treatments $(P=0.456)$. Our data show that small numbers of non-target birds visited the rice-baited plots. However, total number of different individual birds using the plots was unknown.

(C) 2004 Society of Chemical Industry
\end{abstract}

Keywords: DRC-1339; granivorous birds; Icteridae; non-target risk; spring migration

\section{INTRODUCTION}

Sunflower is a valuable crop in North Dakota and South Dakota where collectively about 1.1 billion $\mathrm{kg}$, valued at US $\$ 243$ million, were harvested in 2001.1.2 Expansion of production has been hampered, however, by the inability of wildlife biologists to keep blackbird (Icteridae) damage below economically acceptable levels. ${ }^{3}$ Estimates of annual direct economic losses from blackbird damage consistently exceed $\$ 5$ million. ${ }^{4}$

In response, the US Department of Agriculture is investigating the compound DRC-1339 (3-chloro4-methylaniline, 3-chloro- $p$-toluidine hydrochloride) as a potential tool for managing spring-migrating blackbird populations. This research is concentrated south of the main sunflower-growing areas of North Dakota and northern South Dakota where large concentrations of blackbirds are found prior to breaking up into progressively smaller groups as they migrate to breeding areas. ${ }^{5}$ Reducing the size of this regional population during spring, prior to the breeding effort, might be an effective solution for reducing blackbird damage to sunflower. ${ }^{5}$

DRC-1339 was first developed to control European starlings (Stumus vulgaris L) at feedlots. ${ }^{6}$ In the 1960 s, DRC-1339-baited cracked corn was tested for baiting spring-migrating blackbird populations in South Dakota, but was determined to be ineffective. ${ }^{7}$ During the 1980s, DRC-1339-baited rice was successfully developed for baiting blackbirds in Louisiana to protect sprouting rice. ${ }^{8}$ In the following decade, DRC-1339-baited rice was used to develop baiting strategies for reducing the number of spring-migrating blackbirds in North Dakota and South Dakota. ${ }^{5}$ The only two quantitative studies conducted in our study area showed that non-blackbird (non-target) use of rice-baited plots in harvested corn fields was low. 9,10 Despite intensive searches by humans and trained dogs, no non-target birds were found that had succumbed to DRC-1339.9,10 However, non-target bird use of rice-baited plots in soybean fields was not studied, and questions have persisted about the potential risks of using rice baits in harvested com in eastern South Dakota. ${ }^{11}$

*Correspondence to: George M Linz, USDA, Wildlife Services, National Wildlife Research Center, 2110 Miriam Circle, Suite B, Bismarck, ND 58501, USA

E-mail: george.m.linz@usda.gov

†Present address: US Fish and Wildlife Service, Long Lake National Wild life Refuge \& Wetland Management District, 12000 - 353 rd St SE, Moffit, ND 58560, USA

Contract/grant sponsor: Wildlife Services Program of the US Department of Agriculture, Animal and Plant Health Inspection Service

Contract/grant sponsor: Department of Biological Sciences, North Dakota State University

(Received 27 June 2003; revised version received 11 March 2004; accepted 6 April 2004)

Published online 15 June 2004 
Acute oral toxicity tests show that there are differential toxicities of DRC-1339 dosages among bird species. ${ }^{12}$ In the more susceptible $\left(\mathrm{LD}_{50}<\right.$ $20 \mathrm{mg} \mathrm{kg}^{-1}$ ) birds (blackbirds, doves, pheasants), DRC-1339 causes irreversible kidney and heart damage leading to death $24-72 \mathrm{~h}$ following ingestion. ${ }^{12}$ DRC-1339 is highly $\left(\mathrm{LD}_{50}=10-50 \mathrm{mg} \mathrm{kg}^{-1}\right)$ to moderately toxic $\left(\mathrm{LD}_{50}=51-500 \mathrm{mg} \mathrm{kg}^{-1}\right)$ to most sparrows, finches and waterfowl. However, repeated exposure to sublethal doses of DRC-1339 can result in death for resistant birds as well. ${ }^{13}$ DRC-1339 does not appear to affect reproduction except at levels very close to those where toxicity is expressed. ${ }^{13,14} \mathrm{~A}$ single DRC-1339-baited rice grain is sufficient to kill smaller susceptible birds, but larger birds, such as pheasants, might need to eat 25 treated seeds to obtain a lethal dose. ${ }^{15}$ With data showing that DRC-1339 is toxic to some non-target species of birds, it seems prudent to determine which susceptible species might be exposed to treated baits.

In the springs of 1996 and 1997, we compared non-target granivorous bird use of rice-baited plots and unbaited reference plots placed in harvested fields of corn and soybean in eastern South Dakota. Our objectives were to identify granivorous birds using the plots and quantify bird-use of rice-baited and unbaited reference plots placed in harvested corn and soybean fields. This information may be used to design blackbird baiting programs while minimizing non-target bird impacts.

\section{STUDY AREA}

The study area was in Brookings, Miner and Lake counties in eastern South Dakota. This area was chosen because it is considered to be the most northern region where migrating flocks of blackbirds are large enough to warrant a baiting program. ${ }^{5}$ Eastern South Dakota lies in the Coteau Des Prairies physiographic region in the Central Lowland province. ${ }^{16}$ The landscape is characterized by low, rolling hills and a variety of glacial till deposits; undrained lakes and small. wetland basins abound. Formerly tallgrass prairie, the land now consists mainly of pasture and row crops. Shelterbelts and windbreaks divide expansive field crops and surround farmsteads and residential areas. Corn and soybean are the principal crops in eastern South Dakota, comprising $92 \%$ of the planted crops.

The long-term average temperature and precipitation during March and April in eastern South Dakota are $3.3^{\circ} \mathrm{C}$ and $4.6 \mathrm{~cm}$, respectively. ${ }^{2}$ During our 2year study, temperatures and precipitation were below average for March and April. In 1996, the temperature averaged $0.2^{\circ} \mathrm{C}$ and precipitation was $1.3 \mathrm{~cm}$. In 1997, the average temperature was $0.9^{\circ} \mathrm{C}$ and precipitation was $3.8 \mathrm{~cm} .{ }^{2}$ An intense early spring storm entered the study area on 5-6 April 1997 and was followed by record cold $\left(-15^{\circ} \mathrm{C}\right)$ from April 8 to 12 .

\section{METHODS}

In mid-March 1996, we selected three fields each of harvested soybean and corn located within $1.6 \mathrm{~km}$ of blackbird roosts. We placed one pair of plots of equal size $(\sim 1.1 \mathrm{ha})$ in each field about $50 \mathrm{~m}$ apart. One member of each pair was baited with brown rice; the other served as an unbaited reference. In mid-March 1997, we selected four harvested fields of each crop and standardized the size of the plots at $0.8 \mathrm{ha}$.

We applied $22.7 \mathrm{~kg}$ of brown rice once or twice per week using a seed broadcaster mounted on an all-terrain vehicle. The frequency of baiting mimics a potential operational program. ${ }^{5}$ We marked the corners of each plot with colored stakes to assist the observers in delineating plot boundaries. We scanned the paired plots from a blind siruated $3 \mathrm{~m}$ above ground level and mounted on a pickup truck parked about $25 \mathrm{~m}$ from the plots. After a $30-\mathrm{min}$ period of quiet, a single observer recorded the species and numbers of birds using the plots. Observation periods lasted $1 \mathrm{~h}$ with 1 -min counts alternating on each plot every $5 \mathrm{~min}$ ( 12 observations $\mathrm{h}^{-1}$ ). All observations were made by a pool of four trained observers. In both years, the study started after the snow had melted and ended when spring cultivation was initiated. Observations were not conducted during periods of snow, rain or wind $>32 \mathrm{~km} \mathrm{~h}^{-1}$.

In 1996, we observed the paired plots in random order from 21 March to 26 April during four equal time strata. In 1997, we observed paired plots in random order from 29 March to 29 April during two equal time strata. We eliminated the two mid-day time strata in 1997 because bird activity had been comparatively low in these strata during 1996.

\section{STATISTICAL ANALYSES}

We used mean number of birds per minute of observation during the 1681 -h periods as the measurement unit for analyzing bird activity in the plots. We analyzed count data for individual species occurring in $>10 \%$ of the 1 -h timed observations. The majority of species were seen infrequently and thus were grouped into the general category of granivorous species. Prior to statistical analysis, the count data for individual species and all granivorous species combined were transformed using the square root to increase normality. ${ }^{17}$ Our study was designed as a three-factor (ie Date, Crop, Treatment) experiment with two repeated measures factors (ie Date, Treatment). We used the Proc GLM procedure to examine null hypotheses that the mean numbers of birds were similar between harvested corn and soybean fields, between rice-baited and unbaited plots, and among dates within year. ${ }^{18}$ Interactions among treatments (unbaited and baited) date within year (1996 and 1997) and between crops (soybean and corn) also were tested to examine for differences in trends in bird numbers. We set the significance level at 0.10 because (1) resources were not sufficient 
to increase sample sizes and (2) the consequences of accepting false null hypotheses (Type II errors) on populations of birds using DRC-1339-baited plots are much greater than if Type I errors (rejecting true null hypotheses) were made. ${ }^{19}$

\section{RESULTS}

\subsection{Bird species}

We identified 16 species of granivorous non-target birds (Tables 1, 2) in 1996 and 1997. Across both study years, western meadowlarks (17.3\%) occurred most often, followed by horned larks $(10.4 \%)$, American tree sparrows $(7.7 \%)$, song sparrows $(6.0 \%)$, vesper sparrows $(5.0 \%)$, Lapland longspurs $(4.8 \%)$, mourning doves $(2.4 \%)$, mallard ducks (1.8\%); ring-necked pheasants (1.8\%), Canada geese $(1.5 \%)$ and American coots $(1.5 \%)$. The remaining five birds, dark-eyed junco, chipping sparrow, savannah sparrow, gray partridge and snow bunting were recorded during $<1 \%$ of the observations hours. Dark-eyed juncn, chipping sparrow, and snow bunting were recorded in 1996 but not in 1997. Lapland longspur, American coot, Canada goose, vesper sparrow, gray partridge and savannah sparrow were observed in 1997 but not in 1996.

In 1996, we counted 349 granivorous birds during 71 observation hours. Western meadowlarks and American tree sparrows were observed during $>10 \%$ of the hour observations. In 1997, we recorded 3,326 non-blackbird granivorous birds during $97 \mathrm{~h}$. Western meadowlarks and horned larks were observed during

Table 1. Mean numbers of granivorous birds, excluding biackbirds, present in harvested corn and soybean fields in eastern South Dakota from 21 March to 26 April 1996 and from 29 March to 29 April 1997

\begin{tabular}{|c|c|c|c|c|c|c|c|c|}
\hline \multirow[b]{3}{*}{ Name } & \multicolumn{4}{|c|}{1996} & \multicolumn{4}{|c|}{1997} \\
\hline & \multicolumn{2}{|c|}{ Corn } & \multicolumn{2}{|c|}{ Soybean } & \multicolumn{2}{|c|}{ Corn } & \multicolumn{2}{|c|}{ Soybean } \\
\hline & \multicolumn{2}{|c|}{$\begin{array}{l}\text { Mean number } \\
\text { of birds } \min ^{-1} \\
(n=28 \mathrm{~h})^{\mathrm{a}} \text { (SE) }\end{array}$} & \multicolumn{2}{|c|}{$\begin{array}{l}\text { Mean number } \\
\text { of birds } \min ^{-1} \\
(n=43 \mathrm{~h})^{\mathrm{a}}(\mathrm{SE})\end{array}$} & \multicolumn{2}{|c|}{$\begin{array}{l}\text { Mean number } \\
\text { of birds } \text { min }^{-1} \\
(n=46 h)^{\mathrm{a}} \text { (SE) }\end{array}$} & \multicolumn{2}{|c|}{$\begin{array}{l}\text { Mean number } \\
\text { of birds } \mathrm{min}^{-1} \\
(n=51 \mathrm{~h})^{\mathrm{a}}(\mathrm{SE})\end{array}$} \\
\hline Lapland longspur & & & & & & & & \\
\hline $\begin{array}{l}\text { Calcarius lapponicus L } \\
\text { American tree sparrow }\end{array}$ & 0.00 & 0.000 & 0.00 & 0.000 & 0.00 & 0.000 & 1.65 & 0.955 \\
\hline $\begin{array}{l}\text { Spizella arborea (Wilson) } \\
\text { American coot }\end{array}$ & 0.08 & 0.072 & 0.11 & 0.064 & 0.01 & 0.009 & 0.03 & 0.030 \\
\hline $\begin{array}{l}\text { Fulica americana Gmelin } \\
\text { Western meadowlark }\end{array}$ & 0.00 & 0.000 & 0.00 & 0.000 & 0.50 & 0.439 & 0.00 & 0.000 \\
\hline $\begin{array}{l}\text { Sturnella neglecta Audubon } \\
\text { Song sparrow }\end{array}$ & 0.03 & 0.015 & 0.05 & 0.025 & 0.02 & 0.006 & 0.03 & 0.010 \\
\hline $\begin{array}{l}\text { Melospiza melodia (Milson) } \\
\text { Canada goose }\end{array}$ & 0.04 & 0.036 & $<0.01$ & 0.005 & $<0.01$ & 0.005 & 0.03 & 0.019 \\
\hline $\begin{array}{l}\text { Branta canadensis (L) } \\
\text { Mallard }\end{array}$ & 0.00 & 0.000 & 0.00 & 0.000 & 0.03 & 0.019 & 0.00 & 0.000 \\
\hline $\begin{array}{l}\text { Anas platyrhynchos } L \\
\text { Homed lark }\end{array}$ & 0.00 & 0.000 & 0.04 & 0.034 & $<0.01$ & 0.007 & 0.00 & 0.000 \\
\hline $\begin{array}{l}\text { Eremophilla alpestris (L) } \\
\text { Snow bunting }\end{array}$ & 0.00 & 0.000 & $<0.01$ & 0.006 & $<0.01$ & 0.005 & 0.06 & 0.020 \\
\hline $\begin{array}{l}\text { Plectrophenax nivalis (L) } \\
\text { Dark-eyed junco }\end{array}$ & 0.00 & 0.000 & $<0.01$ & 0.004 & 0.00 & 0.000 & 0.00 & 0.000 \\
\hline $\begin{array}{l}\text { Junco hyemalis }(L) \\
\text { Chipping sparrow }\end{array}$ & 0.00 & 0.000 & $<0.01$ & 0.004 & 0.00 & 0.000 & 0.00 & 0.000 \\
\hline $\begin{array}{l}\text { Spizella passerina (Bechstein) } \\
\text { Vesper sparrow }\end{array}$ & 0.01 & 0.000 & $<0.01$ & 0.004 & 0.00 & 0.000 & 0.00 & 0.000 \\
\hline $\begin{array}{l}\text { Pooecetes gramineus (Gmelin) } \\
\text { Savannah sparrow }\end{array}$ & 0.00 & 0.000 & 0.00 & 0.000 & $<0.01$ & 0.004 & 0.04 & 0.021 \\
\hline $\begin{array}{l}\text { Passerculus sandwichensis (Gmelin) } \\
\text { Ring-necked pheasant }\end{array}$ & 0.00 & 0.000 & 0.00 & 0.000 & 0.00 & 0.000 & $<0.01$ & 0.002 \\
\hline $\begin{array}{l}\text { Phasianus colchicus } L \\
\text { Gray partridge }\end{array}$ & 0.01 & 0.007 & 0.00 & 0.000 & $<0.01$ & 0.006 & $<0.01$ & 0.006 \\
\hline $\begin{array}{l}\text { Perdix perdix } L \\
\text { Mourning dove }\end{array}$ & 0.00 & 0.000 & 0.00 & 0.000 & 0.00 & 0.000 & $<0.01$ & 0.001 \\
\hline $\begin{array}{l}\text { Zenaida macroura (L) } \\
\text { Unidentified sparrow }\end{array}$ & 0.00 & 0.000 & $<0.01$ & 0.004 & 0.01 & 0.012 & $<0.01$ & 0.001 \\
\hline Emberizidae & 0.00 & 0.000 & 0.00 & 0.000 & 0.00 & 0.000 & $<0.01$ & 0.001 \\
\hline All granivores & 0.15 & 0.080 & 0.24 & 0.082 & 0.60 & 0.445 & 1.85 & 0.952 \\
\hline
\end{tabular}

${ }^{\text {a }}$ Plots were observed for $1 \mathrm{~min}$ at 12 consecutive 5 - $\mathrm{min}$ intervals and averaged over the $\mathrm{i}$-h observation period. 
Table 2. Mean numbers of granivorous birds, excluding blackbirds, present in rice-baited and unbaited reference plots placed in fields of soybean in eastern South Dakota from 21 March to 26 April 1996 and from 29 March to 29 April 1997

\begin{tabular}{|c|c|c|c|c|c|c|c|c|}
\hline \multirow{4}{*}{$\frac{\text { Name }}{\text { Lapland longspur }}$} & \multicolumn{4}{|c|}{1996} & \multicolumn{4}{|c|}{1997} \\
\hline & \multirow{2}{*}{\multicolumn{2}{|c|}{$\begin{array}{c}\text { Unbaited reference } \\
\text { Mean number } \\
\text { of birds min } \\
(n=71 \mathrm{~h})^{\mathrm{a}} \text { (SE) }\end{array}$}} & \multirow{2}{*}{\multicolumn{2}{|c|}{$\begin{array}{l}\text { Rice baited } \\
\text { Mean number } \\
\text { of birds } \min ^{-1} \\
(n=71 \mathrm{~h})^{\mathrm{a}} \text { (SE) }\end{array}$}} & \multirow{2}{*}{\multicolumn{2}{|c|}{$\begin{array}{l}\text { Unbaited reference } \\
\text { Mean number } \\
\text { of birds } \min ^{-1} \\
(n=97 h)^{\mathrm{a}}(\mathrm{SE})\end{array}$}} & \multirow{2}{*}{\multicolumn{2}{|c|}{$\begin{array}{c}\text { Rice baited } \\
\begin{array}{c}\text { Mean number } \\
\text { of birds } \min ^{-1} \\
(n=97 \mathrm{~h})^{\mathrm{a}}(\mathrm{SE})\end{array}\end{array}$}} \\
\hline & & & & & & & & \\
\hline & 0.00 & 0.000 & 0.00 & 0.000 & 0.10 & 0.060 & 1.64 & 0.708 \\
\hline American tree sparrow & 0.03 & 0.020 & 0.19 & 0.160 & 0.02 & 0.017 & 0.02 & 0.015 \\
\hline American coot & 0.00 & 0.000 & 0.00 & 0.000 & 0.10 & 0.080 & 0.38 & 0.285 \\
\hline Canada goose & 0.00 & 0.000 & 0.00 & 0.000 & 0.02 & 0.012 & $<0.01$ & 0.009 \\
\hline Western meadowiark & 0.02 & 0.010 & 0.06 & 0.021 & 0.01 & 0.004 & 0.04 & 0.008 \\
\hline Song sparrow & $<0.01$ & 0.004 & 0.01 & 0.007 & 0.01 & 0.006 & 0.03 & 0.014 \\
\hline Mallard & 0.04 & 0.027 & 0.01 & 0.012 & $<0.01$ & 0.000 & 0.00 & 0.000 \\
\hline Horned lark & $<0.01$ & 0.004 & $<0.01$ & 0.003 & 0.03 & 0.013 & 0.03 & 0.009 \\
\hline Vesper sparrow & 0.00 & 0.000 & 0.00 & 0.000 & 0.02 & 0.011 & 0.02 & 0.012 \\
\hline Ring-necked pheasant & 0.01 & 0.007 & 0.00 & 0.000 & $<0.01$ & 0.004 & $<0.01$ & 0.004 \\
\hline Mourning dove & $<0.01$ & 0.004 & 0.00 & 0.000 & 0.01 & 0.008 & $<0.01$ & 0.002 \\
\hline Dark-eyed junco & 0.00 & 0.000 & $<0.01$ & 0.003 & 0.00 & 0.000 & 0.00 & 0.000 \\
\hline Chipping sparrow & $<0.01$ & 0.004 & 0.00 & 0.000 & 0.00 & 0.000 & 0.00 & 0.000 \\
\hline Snow bunting & 0.00 & 0.000 & $<0.01$ & 0.004 & 0.00 & 0.000 & 0.00 & 0.000 \\
\hline Savannah sparrow & 0.00 & 0.000 & 0.00 & 0.000 & 0.00 & 0.000 & $<0.01$ & 0.002 \\
\hline Gray partridge & 0.00 & 0.000 & $<0.01$ & $<0.001$ & 0.00 & 0.000 & $<0.01$ & $<0.001$ \\
\hline Unidentified sparrow & 0.00 & 0.000 & 0.02 & 0.017 & $<0.01$ & $<0.001$ & 0.00 & 0.000 \\
\hline Total & 0.12 & 0.043 & 0.29 & 0.071 & 0.34 & 0.110 & 2.17 & 0.754 \\
\hline
\end{tabular}

a Plots were observed for $1 \mathrm{~min}$ at 12 consecutive 5 -min intervals and averaged over the 1 -h observation period.

$>10 \%$ of the observation hours. The increase in bird numbers between 1996 and 1997 was largely due to lingering migratory flocks of Lapland longspurs feeding in soybean fields (Table 2).

\subsection{Corn vs soybean}

We recorded 11 and 14 granivorous bird species in corn and soybean fields, respectively. Of these species, 9 were common to both crops (Table 1). In $1996(X=0.20, \mathrm{SE}=0.042)$ and $1997(X=1.24$, $\mathrm{SE}=0.382)$, average granivore numbers $\mathrm{min}^{-1}$ were not significantly different among observation dates ( $P$ range $=0.120-0.899$ ) .

In 1996, numbers of American tree sparrow, western meadowlark and total granivorous birds were similar between harvested fields of corn and soybean ( $P$ range $=0.322-0.914)$, averaging 0.10 birds $\min ^{-1}(\mathrm{SE}=0.034), 0.04$ birds $\min ^{-1}(\mathrm{SE}=0.012)$ and 0.20 birds $\mathrm{min}^{-1}(\mathrm{SE}=0.042)$, respectively. There was a marginally significant crop and date interaction for western meadowlarks $(P=0.092)$ because the birds tended to use corn fields in early April and soybean fields in late April.

In 1997, horned larks $(X=0.03, \mathrm{SE}=0.008)$, western meadowlarks $(X=0.02, \mathrm{SE}=0.004)$, and total granivorous bird ( $X=1.24, \mathrm{SE}=0.382)$ abundances did not differ between corn and soybean fields ( $P$ range $=0.122-0.473$ ). The crop type and date interaction was significant for horned larks $(P<0.001)$ due to high numbers of birds using ricebaited soybean fields in early April, while few used corn fields throughout the study.

\subsection{Rice-baited vs unbaited reference}

In 1996, total numbers of American tree sparrows, western meadowlarks, and total granivorous birds were significantly different ( $P$ range $=0.069-0.087$ ) between rice-baited and unbaited reference plots (Table 2). In 1997, total numbers of horned larks, western meadowlarks, and total granivores did not differ between rice-baited and untreated plots ( $P$ range $=0.299-0.494)$. Interactions between treatment and date were not significant in 1996 ( $P$ range $=$ $0.529-0.826)$ or 1997 ( $P$ range $=0.185-0.458$ )

\section{DISCUSSION}

We observed 16 granivorous bird species in study plots placed in fields of harvested corn and soybean. Earlier studies found 13 bird species in similarly placed and sized plots in corn fields during 1995, 91998 and 1999. ${ }^{10}$ These researchers recorded four species that we did not record: green-winged teal (Anas crecca L), American widgeon ( $A$ americana $\mathrm{Gmelin})$, wood duck (Aix sponsa $(\mathrm{L})$ ) and house sparrow (Passer domesticus L). Thus, across five consecutive springs and three separate studies, 20 granivorous bird species were recorded in plots in eastern South Dakota. These species probably represent nearly all birds that would frequent roadside plots from late March to late April.

Our data showed that horned larks preferred harvested soybean fields over harvested corn fields. Castrale $^{20}$ also found that horned larks selected soybean over corn fields in southeastern Indiana. These results were not surprising because horned 
larks are considered open land birds. ${ }^{16}$ The gregarious nature, small size and granivorous food habits of horned larks might be reasons for concern. However, the $\mathrm{LD}_{50}$ acute toxicity test for the horned lark showed that these birds are less susceptible to DRC-1339 than are blackbirds. ${ }^{12}$

Western meadowlarks and American tree sparrows seem at greatest risk from spring baiting in eastern South Dakota. A singie rice kernel, treated with $0.4 \mathrm{mg}$ DRC-1339, is fatal for both species. Western meadowlarks are at risk because they eat rice ${ }^{21}$ and were seen in our bait plots singly and in pairs throughout the study period. In 1997, American tree sparrows were present in the bait plots in flocks up to 20 birds for about 3 days in early April. However, these birds prefer to eat small weed seeds and waste grains, ${ }^{22}$ and might select against rice when alternative food is available. Other sparrow species are believed to be less sensitive to IRC-1339. ${ }^{12,23}$

In our study, granivorous birds generally preferred rice-baited plots to unbaited reference plots, indicating an attraction to rice baits as a food source. Similariy, Smith ${ }^{10}$ also found that granivorous birds were attracted to rice. On the other hand, Linz et al. ${ }^{9}$ reported comparable numbers of birds in rice-baited and reference plots in corn stubble fields in the same study area that we used in eastern South Dakota. We cannot explain the difference in results among studies. It seems reasonable, however, that some seed-eating birds could be attracted to rice.

\section{CONCLUSIONS AND MANAGEMENT IMPLICATIONS}

Our data support the contention of $\mathrm{Smith}^{10}$ and Linz et $a l^{9}$ that a spring blackbird baiting program with DRC-1339-treated rice bait presents a potential hazard to granivorous birds. However, both exposure and susceptibility of non-target birds to DRC-1339 must be considered prior to a complete assessment of risk. Exposure depends on feeding ecology, habitat use, abundance, and availability of DRC-1339, putting some avian species more at risk than others. Western meadowlarks and American tree sparrows are the species most at risk in eastern South Dakota because of their food habits, relative numbers and susceptibility to DRC-1339. Other birds could be at risk, if conditioned to visit baited plots. Any planned baiting program would involve using a diluted bait ratio of one treated to 25 untreated rice kernels or greater and $<25-0.8$-ha plots, ${ }^{5}$ which might reduce non-target exposure.

\section{ACKNOWLEDGEMENTS}

We thank B Check, J Tharman, J Wendel, B Bonesteel, and $T$ Slowik for field assistance. This research was cooperatively funded by the National Wildlife Research Center, a unit within the Wildlife Services Program of the US Department of Agriculture, Animal and Plant Health Inspection Service, and the
Department of Biological Sciences at North Dakota State University. This study was conducted under National Wildlife Research Center Study Protocol QA-437, as amended.

\section{REFERENCES}

1 North Dakota Agricultural Statistics Service (NDASS), North Dakota Agricultural Statistics 2001, North Dakota Agricultural Statistics Service, Fargo, North Dakota, USA (2002).

2 South Dakota Agricultural Statistics Service (SDASS), South Dakotc Agricultural Statistics 2001, South Dakota Agricultural Statistics Service, Sioux Falls, South Dakota, USA (2002).

3 Linz GM and Hanzel JJ, Birds and sunflower, in Sunflower science and technology, ed by Schneider A, ASA Publication No 35, American Society for Agronomy, Madison, Wisconsin, USA, pp 381-394 (1997).

4 Peer $\mathrm{BD}$, Homan HJ, Linz $\mathrm{GM}$ and Bleier WJ, Impact of blackbird damage to sunflower: bioenergetic and economic models. Ecol Applic 13:248-256 (2003).

5 Linz GM, Knutsen GA, Homan H] and Bleier WJ, Baiting blackbirds (Icteridae) in stubble grain fields during spring migration in South Dakota. Crop Prot 22:261-264 (2003).

6 DeCino TJ, Cunningham DJ and Schafer EW, Toxicity of DRC-1339 to starlings. 7 Wild Manag 30:249-253 (1966).

7 Larsen $\mathrm{KH}$ and Besser JF, The effectiveness of DRC-1339 as a toxicant for red-winged blackbirds and the utility of early spring baiting in a com damage problem, Sand Lake Refuge, South Dakota, US Bureau of Sport Fish and Wildlife, Denver Wildlife Research Center, Lakewood, Colorado, USA, unpublished report (1963).

8 Glahn JF and Wilson EA, Effectiveness of DRC-1339 baiting for reducing blackbird damage to sprouting rice. Eastern Wildlife Damage Control Conf 5:1 17-123 (1992).

$9 \mathrm{Linz}$ GM, Kenyon MJ, Homan HJ and Bleier WJ, Avian use of rice-baited corn stubble in east-central South Dakota. Int Biodeterior Biodegrad 49:179-184 (2002).

10 Smith JA, Nontarget avian use of DRC-1339 treated piots during an experimental blackbird control program in eastern South Dakota, Thesis, South Dakota State University, Brookings, South Dakota, USA (1999).

11. Gamble LR, Johnson KM, Linder $G$ and Harrahy EA, The migratory treaty act and congress for non-target birds relative to spring baiting with DRC-1339, in Management of North American Blackbirds, ed by Linz GM, US Department of Agriculture, Animal and Plant Health Inspection Service, Wildlife Services, National Wildlife Research Center, Fort Collins, Colorado, USA, pp 8-12 (2003).

12 Eisemann JD, Linz GM and Johnston JJ, Nontarget hazard assessment of using DRC-1339 avicide to manage blackbirds in sunflower, in Pesticides and wildlife, ed by Johnson J, ACS Symposium Series 771, American Chemical Society, Washington, DC, USA, pp 197-211 (2001).

13 Schafer EW Jr, Brunton RB, Cunningham DJ and Lockyer NF, The chronic toxicity of 3-chloro-4-methyl benzamine $\mathrm{HCL}$ to birds. Arch Environ Contam Toxicol 6:241-248 (1977).

14 Hubbard DE and Neiger RD, Effects of DRC-1339 (3-chloro4-methyl methylaniline) avicide on pheasant reproduction, in Management of North American Blackbirds, ed by Linz GM, US Department of Agriculture, Animal and Plant Heaith Inspection Service, Wildlife Services, National Wildlife Research Center, Fort Collins, Colorado, USA, pp 85-90 (2003).

15 Avery ML, Kenyon MJ, Linz GM, Bergman DL, Decker DG and Humphrey JS. Potential risk to ring-necked pheasants from application of toxic bait for blackbird control in South Dakota. $f$ Wildl Manage 62:388-394 (1998).

16 South Dakota Ornithologists' Union (SDOU), The Birds of South Dakota, 2nd edn. Northern States University Press, Aberdeen, South Dakota, USA (1991). 
17 Montgomery DC, Design and analysis of experiments, 3rd edn. J Wiley \& Sons, New York, USA, 649 pp (1991).

18 Cody RP and Smith JK, Applied statistics and the SAS programming language, 4th edn, Prentice Hall, Englewood Cliffs, New Jersey, USA (1997).

19 Tacha TC, Warde WD and Burnham KP, Use and interpretation of statistics in wildiife journals. Wildl Soc Bull 10:355-362 (1982).

20 Castrale JS, Responses of wildlife to various tillage conditions. Trans North American Wild and Nat Res Conf 50:142-156 (1985).
21 Flickinger EL and King KA, Some effects of aldrin-baited rice on Gulf Coast wildlife. $f$ Wildl Manage 36:706-727 (1972).

22 Naugler CT, American tree sparrow, in Birds of North America No 37, ed by Poole A and Gill F, Academy of Natural Sciences, Washington, DC, USA, pp 1-12 (1993).

23 Cummings $J \mathrm{~L}$, Glahn JF, Wilson EA and Davis JE Jr, Potential hazards of DRC-1339 treated rice to non-target birds when used at roost staging areas in Louisiana to reduce local populations of depredating blackbirds. Int Biodeterior Biodegrad 49:185-188 (2002). 